\title{
A STUDY OF RELATION OF SERUM TESTOSTERONE LEVELS AND ERECTILE DYSFUNCTION IN MALE PATIENTS IN TYPE 2 DIABETES MELLITUS
}

\author{
Dharam Prakash Bansal'1, Piyush Kumar2, Prashant Pathak3 ${ }^{3}$ Ankit Manglunia ${ }^{4}$ \\ ${ }^{1}$ Associate Professor, Department of Medicine, Mahatma Gandhi Medical College and Hospital, Jaipur, Rajasthan. \\ ${ }^{2}$ Chief Resident, Department of Medicine, Mahatma Gandhi Medical College and Hospital, Jaipur, Rajasthan. \\ ${ }^{3}$ Chief Resident, Department of Medicine, Mahatma Gandhi Medical College and Hospital, Jaipur, Rajasthan. \\ ${ }^{4}$ Chief Resident, Department of Medicine, Mahatma Gandhi Medical College and Hospital, Jaipur, Rajasthan.
}

\begin{abstract}
BACKGROUND

A high prevalence of low serum testosterone in men with type 2 diabetes has been reported worldwide. Low serum testosterone and erectile dysfunction are the major consequences found in type $2 \mathrm{DM}$ in recent studies. Establishing this relationship conclusively may have profound effects in the management of diabetes and hypogonadism. These results need to be confirmed in more diabetic men, and, therefore an elaborative study was done to confirm these findings in the Indian population.
\end{abstract}

\section{MATERIALS AND METHODS}

This was a cross-sectional study, conducted among 80 men (Aged 30-70 years) with type 2 diabetes and 40 nondiabetics (aged 30-70 years) who visited Medicine OPD of Mahatma Gandhi Hospital, Jaipur between Feb. 2015 to March 2016. The patients' demographic characteristics were collected using a pre-structured questionnaire. Duration of diabetes, smoking habits, family history, drug history, trauma history, any tumour or radiation history or history of chronic liver and kidney disease were collected. Venous blood sample was collected to test for total testosterone (TT), free testosterone (FT), serum lipids, and glycosylated haemoglobin (HbA1c). In all men, the morning (08.00-10.00 hours) TT and FT levels were measured after an overnight fast. Normal levels of TT were taken as 300-1000 ng/dL and normal levels of FT as 9-40 pg/mL. Presence and degree of ED was assessed by the validated international index of erectile Function-5 (IIEF-5) questionnaire. Erectile dysfunction was considered present when the IIEF - 5 score was $\leq 21$.

\section{RESULTS}

Total testosterone $(298.63 \pm 24.75)$ in patients with type 2 DM were significantly lower as compared to control $(383.81 \pm 58.36)$ $\mathrm{p}<0.001$. Free testosterone $(7.61 \pm 2.12)$ in patients with type $2 \mathrm{DM}$ were significantly lower as compared to control $(11.17 \pm 2.34)$ $\mathrm{p}<0.001$. IIEF-5 score was significantly low in type 2 DM (14.62 \pm 5.39$)$ as compared to nondiabetic $(23.15 \pm 3.70)$ individuals $\mathrm{p}<0.001$.

\section{CONCLUSION}

Serum total and free testosterone levels were significantly low in patients with type 2 DM. Type 2 Diabetes Mellitus patients were found to have significant erectile dysfunction developing early in first five years of diagnosis.

\section{KEYWORDS}

ED- Erectile Dysfunction, DM2- Diabetic Mellitus, HTN- Hypertension.

HOW TO CITE THIS ARTICLE: Bansal DP, Kumar P, Pathak P, et al. A study of relation of serum testosterone levels and erectile dysfunction in male patients in type 2 diabetes mellitus. J. Evolution Med. Dent. Sci. 2017;6(23):1833-1837, DOI: $10.14260 /$ Jemds/2017/405

\section{BACKGROUND}

Diabetes mellitus refers to a group of common metabolic disorders that share the phenotype of hyperglycaemia. It is a multifactorial disease which is characterised by hyperglycaemia, dyslipidaemia, involves various organ systems, and results in various long-term complications. Diabetes mellitus (DM) affects an estimated 285 million people worldwide. This number is expected to reach 438 million by the year 2030, with two-thirds of all cases

Financial or Other, Competing Interest: None.

Submission 09-02-2017, Peer Review 06-03-2017,

Acceptance 11-03-2017, Published 20-03-2017.

Corresponding Author:

Dr. Dharam Prakash Bansal,

\#D 304, Ashadeep Green Avenue,

In Front of Akshay Patra Temple,

Jagatpura, Jaipur-302033.

E-mail: pkbrkb@yahoo.com

DOI: $10.14260 /$ jemds $/ 2017 / 405$ occurring in low- to middle- income countries. ${ }^{1}$ With an increasing incidence worldwide, diabetes mellitus will be a leading cause of morbidity and mortality for the foreseeable future. ${ }^{2}$ India leads the world with largest number of diabetic subjects earning the dubious distinction of being termed the "diabetes capital of the world".

Several studies have suggested that men with low testosterone levels are at a greater risk of developing type 2 diabetes mellitus, and that low testosterone levels may even predict the onset of diabetes. ${ }^{3,4,5}$

The association between low serum testosterone (LST) and DM has recently received substantial attention. ${ }^{6,7}$ Studies have reported that men with type 2 DM (T2DM) have a high prevalence of LST.8,9,10 Another complication of diabetes is erectile dysfunction with an estimated prevalence of $20.85 \%$ (Ranging from mild to complete ED) which occurs at an earlier age than in nondiabetic men. ${ }^{11}$

This study was conducted to determine the prevalence and level of low testosterone level and erectile dysfunction in type 2 DM patients in Indian population. 


\section{MATERIALS AND METHODS}

The study was conducted in 80 male subjects with diabetes mellitus type 2 and 40 non-diabetic subjects age and sex matched, attending Diabetic OPD and admitted in medicine ward, Mahatma Gandhi Hospital between March 2015 and February 2016 with official permission and ethical clearance given by ethical committee of Mahatma Gandhi Medical College and Hospital, Jaipur, Rajasthan.

Patients with a known history of hypogonadism, panhypopituitarism, patients not willing for study, patients taking exogenous testosterone, patients with hyperthyroidism, or chronic debilitating disease, such as renal failure, cirrhosis, or HIV, were excluded from the study. The mean level of serum testosterone was calculated in various age and BMI groups and compared with controls.

TT was measured by fully automated bi-directionally interfaced chemiluminescent immunoassay (CLIA) and FT was measured by radio immune assay (RIA), with an intraassay coefficient of variation of $2.6 \%$ and an inter assay coefficient of variation of $4.3 \%$. Normal levels of TT were taken as $300-1000 \mathrm{ng} / \mathrm{dL}$ and normal levels of FT as 9-40 $\mathrm{pg} / \mathrm{mL}$. Presence of diabetes mellitus was defined as per American Diabetes Association Criteria.

Presence and degree of ED was assessed by the validated international Index of Erectile Function-5 (IIEF-5) questionnaire. Erectile dysfunction was considered present when the IIEF-5 score was $\leq 21$.

\section{Statistical Method}

- $\quad$ For different qualitative parameters mean and standard deviation calculated.

- To compare the means between two groups, student unpaired ' $\mathrm{t}$ ' test is used. Level of significance is taken as $\mathrm{p}<0.05$.

- Chi square test is used to find the association between two qualitative variables.

\section{Statistical Analysis}

The data was coded and entered into Microsoft Excel spreadsheet. Analysis was done using SPSS version 20 (IBM SPSS Statistics Inc., Chicago, Illinois, USA) Windows software program. The variables were assessed for normality using the Kolmogorov Smirnov test. Descriptive statistics included computation of means and standard deviations. Level of significance was set at $\mathrm{P} \leq 0.05$.

\section{RESULTS}

\begin{tabular}{|c|c|c|}
\hline Age in Years & Case N (\%) & Control N (\%) \\
\hline $30-40$ & $15(18.75 \%)$ & $10(25 \%)$ \\
\hline $41-50$ & $32(40 \%)$ & $15(37.5 \%)$ \\
\hline $51-60$ & $28(35 \%)$ & $12(30 \%)$ \\
\hline$>60$ & $5(6.25 \%)$ & $3(7.25 \%)$ \\
\hline Total & $\mathbf{8 0}$ & $\mathbf{4 0}$ \\
\hline \multicolumn{2}{|c|}{ Table 1. Distribution According to Age } \\
\hline
\end{tabular}

Table 1 shows age distribution among case and control groups. Most of subjects were from 41 - 60 year age groups among both case $(75 \%)$ and control (67.5\%) groups.

\begin{tabular}{|c|c|c|c|}
\hline Variables & Case & Control & P value \\
\hline Age (Mean in years) & $\begin{array}{l}48.32 \pm \\
8.25\end{array}$ & $\begin{array}{l}47.02 \pm \\
9.54\end{array}$ & 0.44 \\
\hline $\begin{array}{l}\text { Body mass index } \\
\text { (Mean in } \mathrm{kg} / \mathrm{m}^{2} \text { ) }\end{array}$ & $\begin{array}{c}27.11 \pm \\
4.603\end{array}$ & $\begin{array}{c}27.07 \pm \\
3.608\end{array}$ & 0.96 \\
\hline $\begin{array}{l}\text { Systolic Blood Pressure } \\
\text { (Mean in mmHg) }\end{array}$ & $\begin{array}{c}127.75 \pm \\
11.202\end{array}$ & $\begin{array}{c}120.4 \pm \\
7.24\end{array}$ & $\begin{array}{l}<0.001 \\
(S)\end{array}$ \\
\hline $\begin{array}{l}\text { Diastolic Blood Pressure } \\
\text { (Mean in mmHg) }\end{array}$ & $\begin{array}{l}80.25 \pm \\
5.63 \\
\end{array}$ & $\begin{array}{c}78.6 \pm \\
3.62 \\
\end{array}$ & 0.09 \\
\hline $\begin{array}{l}\text { Dyslipidaemia }(\mathrm{HDL}<40 \\
\mathrm{mg} / \mathrm{dL}, \mathrm{TG}>150 \mathrm{mg} / \mathrm{dL})\end{array}$ & $\mathrm{n}=72$ & $\mathrm{n}=14$ & $0.01(\mathrm{~S})$ \\
\hline Smoking & $n=24$ & $n=8$ & $0.01(\mathrm{~S})$ \\
\hline Alcohol & $n=9$ & $\mathrm{n}=4$ & 0.22 \\
\hline Family history & $n=40$ & $n=6$ & $0.01(\mathrm{~S})$ \\
\hline
\end{tabular}

Table 2 provided general characteristics of the study variables. Systolic blood pressure $(127.75,120.4)$, dyslipidaemia $(72,14)$, smoking $(24,8)$ and family history $(40,6)$ showed statistically significant results among subjects with type $2 \mathrm{DM}$ and control groups respectively.

\begin{tabular}{|c|c|c|c|}
\hline & $\begin{array}{c}\text { Case } \\
\text { Mean + std } \\
\text { Deviation }\end{array}$ & $\begin{array}{c}\text { Control } \\
\text { Mean + std } \\
\text { Deviation }\end{array}$ & $P$ value \\
\hline $\begin{array}{c}\text { Total Testosterone } \\
\text { (ng/dL) }\end{array}$ & $\begin{array}{c}298.63 \pm \\
24.75 \\
\end{array}$ & $\begin{array}{c}383.81 \pm \\
58.36 \\
\end{array}$ & $\begin{array}{c}<0.001 \\
(\mathrm{~S})\end{array}$ \\
\hline $\begin{array}{c}\text { Free Testosterone } \\
(\mathrm{pg} / \mathrm{dL})\end{array}$ & $\begin{array}{c}7.61 \pm \\
2.12\end{array}$ & $\begin{array}{c}11.17 \pm \\
2.34\end{array}$ & $\begin{array}{c}<0.001 \\
(\mathrm{~S})\end{array}$ \\
\hline $\begin{array}{c}\text { International } \\
\text { Index Erectile } \\
\text { Function -5 Score }\end{array}$ & $\begin{array}{c}14.62 \pm \\
5.39\end{array}$ & $\begin{array}{c}23.15 \pm \\
3.70\end{array}$ & $\begin{array}{l}<0.001 \\
\text { (S) }\end{array}$ \\
\hline
\end{tabular}

Table 3 showed comparison of testosterone profile among case and control group. Total testosterone, free testosterone and International Index Erectile Function Score (IIEF-5) in case $(298.63,7.61,14.62)$ and control (383.81, $11.17,23.15)$ group respectively showed statistically significant results.

\begin{tabular}{|c|c|}
\hline Case & No. of Participants (\%) \\
\hline $\begin{array}{c}\text { DM2 with ED } \\
\text { (IIEF- 5 Score < 22) }\end{array}$ & $65(81.25 \%)$ \\
\hline $\begin{array}{c}\text { DM2 Without ED } \\
\text { (IIEF- 5 Score > 22) }\end{array}$ & $15(18.75 \%)$ \\
\hline Table 4. Distribution of Erectile Dysfunction in Case Group
\end{tabular}

Table 4. Distribution of Erectile Dysfunction in Case Group

Table 4 shows that out of total 80 DM2 cases, 65 $(81.25 \%)$ patients had erectile dysfunction whereas 15 (18.75\%) didn't had erectile dysfunction which is statistically significant.

\begin{tabular}{|c|c|c|c|c|}
\hline & \multicolumn{4}{|c|}{ Mean \pm Std Deviation } \\
\cline { 2 - 5 } & $<\mathbf{6 . 5 \%}$ & $\mathbf{6 . 5 - 8 \%}$ & $\mathbf{8 - 1 0 \%}$ & $>\mathbf{1 0 \%}$ \\
\hline Total Testosterone & $290.1 \pm$ & 301.02 & $300.65 \pm$ & $291.87 \pm$ \\
(ng/dL) & 26.21 & & 25.53 & 26.67 \\
\hline Free Testosterone & $8.68 \pm$ & $7.54 \pm$ & $7.609 \pm$ & $6.86 \pm$ \\
(pg/dL) & 2.17 & 2.36 & 1.79 & 2.13 \\
\hline International & $15.65 \pm$ & $14.73 \pm$ & $14.44 \pm$ & $13.88 \pm$ \\
Index of Erectile & 6.80 & 5.62 & 5.15 & 4.64 \\
Function-5 Score & & & & \\
\hline \multicolumn{5}{|c|}{ Table 5. Distribution of TT, FT, and IIEF-5 } \\
Score According to HbA1C Level \\
\hline
\end{tabular}


Table presented comparison of HbA1C level with TT, FT and IIEF- 5 score. Total Testosterone (301.02) and IIEF-5 score (15.65) was highest with $6.5-8 \%$ HbA1C level but free Testosterone (8.68) was highest in $<6.5 \% \mathrm{HbA} 1 \mathrm{C}$ score.

\begin{tabular}{|c|c|c|c|}
\hline \multirow{2}{*}{} & \multicolumn{3}{|c|}{ Mean \pm Std Deviation } \\
\cline { 2 - 4 } & $\mathbf{0 - 5}$ & $\mathbf{5 - 1 0}$ & $>\mathbf{1 0}$ \\
& Years & Years & Years \\
\hline \multirow{2}{*}{ Age (Years) } & $44.15 \pm$ & $53.62 \pm$ & $59.33 \pm$ \\
& 6.41 & 5.08 & 2.83 \\
\hline \multirow{2}{*}{ HbA1C (\%) } & $8.38 \pm$ & $7.66 \pm$ & $7.16 \pm$ \\
& 1.32 & 1.53 & 1.38 \\
\hline \multirow{2}{*}{ Total Testosterone (ng/dL) } & $302.68 \pm$ & $151.25 \pm$ & $133.41 \pm$ \\
& 22.85 & 63.73 & 59.27 \\
\hline \multirow{2}{*}{ Free Testosterone (pg/dL) } & $7.86 \pm$ & $7.24 \pm$ & $7.05 \pm$ \\
& 2.25 & 1.89 & 1.80 \\
\hline International Index of & $15.57 \pm$ & $14.06 \pm$ & $11.25 \pm$ \\
Erectile Function- 5 Score & 5.31 & 4.44 & 5.83 \\
\hline \multicolumn{3}{|c|}{ Table 6. Duration of Diabetes } \\
\hline \multicolumn{3}{|c}{} \\
\hline
\end{tabular}

Table 6 revealed the duration of diabetes among various study variables. TT, FT, and IIEF-5 score decreases as the duration of DM2 progressed.

\begin{tabular}{|c|c|c|c|}
\hline \multirow{2}{*}{ BMI (kg/m $\mathbf{m}^{2}$} & $\begin{array}{c}\text { Total } \\
\text { Testosterone } \\
<\mathbf{3 0 0} \mathbf{~ n g} / \mathbf{m L}\end{array}$ & $\begin{array}{c}\text { Free } \\
\text { Testosterone } \\
\mathbf{< 9} \mathbf{~ p g} / \mathbf{m L}\end{array}$ & \multirow{2}{*}{ Total } \\
\cline { 2 - 3 } & $\mathbf{( N = )}$ & $\mathbf{( N = )}$ & \\
\hline$<18.5$ (Underweight) & 0 & 1 & 4 \\
\hline $18.5-24.9$ (Normal) & 2 & 9 & 22 \\
\hline $25-29.9$ (Overweight) & 5 & 16 & 28 \\
\hline$>30$ (Obese) & 16 & 20 & 26 \\
\hline Total & $\mathbf{2 3}$ & $\mathbf{4 6}$ & $\mathbf{8 0}$ \\
\hline P value & $0.001($ S) & $0.04($ S) & \\
\hline \multicolumn{2}{|c|}{ Table 7. Study Of BMI with Low Total } \\
Testosterone and Free Testosterone in Case Group \\
\hline
\end{tabular}

Table 7 shows the comparison of BMI with low total and free testosterone. Overweight and obese cases show low level of total and free testosterone.

\section{DISCUSSION}

\section{Distribution According to Age}

It has been documented in the literature that serum testosterone levels decreased with age. After age of 30 years, $1-2 \%$ of serum testosterone levels decrease with every year as a part of normal ageing process. But few recent studies have shown that decrease in serum testosterone level with age is not normal (Guay et al $^{12}$ 2003). The mean age in the present study was $48.32 \pm 8.20$ in case group and $47.02 \pm$ 9.42 in control group. Majority of the cases (40.1\%) and controls $(37.5 \%)$ were in age groups of $41-50$ yrs. The mean age in the study by Koopman et al ${ }^{13}$ (2005) was $46.01 \pm 1.27$ yrs. According to Gale et al ${ }^{14}$ (2010), the average age of onset of diabetes mellitus type 2 in Indian population is 42.5 years. The present study was comparable to that seen in Koopman et al13 2005 study (46.01 years).

\section{Distribution According to Serum Testosterone}

In the present study, 23 out of 80 type 2 diabetes mellitus patients (28.75\%) and 8 out of 40 controls (25\%) had low level of total testosterone in serum, whereas 46 out of 80 diabetes mellitus patients (57.5\%) and 8 out of 40 controls (25\%) had low levels of free testosterone. The Mean serum total testosterone in cases was $298.63 \pm 24.75$ and in control group was $383.81 \pm 58.36$. The difference was statistically significant. The Mean serum free testosterone in cases was $7.61 \pm 2.12$ and in control group was $11.17 \pm 2.34$. The difference was statistically significant.

In the study by Ernani et al ${ }^{15}$ (2005), low levels of serum total testosterone were found in patients with diabetes mellitus (34\%) much when compared to healthy control subjects $(23 \%)$. In the study by Kapoor et al ${ }^{16}$ (2007), low levels of total testosterone were found in $25 \%$ of patients with diabetes mellitus. In the study by Ernaniet al ${ }^{15}$ (2005), level of free testosterone was decreased in $46 \%$ of diabetics as compared to $24 \%$ in non-diabetics. In the study by Koopar et al ${ }^{16}$ (2007), $42 \%$ of patients with DM type 2 had low levels of serum free testosterone.

In the present study, the low levels of serum total and free testosterone in DM2 patients and control group were comparable to other previous studies.

\section{Study of Erectile Dysfunction in Patient of DM2}

In the present study, out of 80 diabetic males, the erectile dysfunction was present in $65(81.25 \%)$ patients. Out of which 14 (17.5\%) had mild ED and 30 (37.5\%) patients had moderate and 21 (26.25\%) had severe ED.

Schiavi et al ${ }^{17}$ studied 40 diabetic men, free from other illness or drugs that could affect sexual capacity and 40 agematched healthy control subjects. ED was present in $77 \%$ of patients. Sundaram et al ${ }^{18}$ reported that in diabetic patients, the prevalence of ED was $66 \%$. Ledda et al $^{19}$ reported that ED was very common among diabetic patients.

\section{Correlation of Erectile Dysfunction in DM2 with Duration of DM2}

Other studies have been reported that long duration of DM2 and poorer glycaemic control in diabetic men were significant predictors of ED in diabetic men. ${ }^{20,21}$ In the present study, duration of DM2 were associated with ED $(\mathrm{p}<0.05)$. This could be due to decreased utilisation of glucose by pituitary cells. However, as expected long duration of DM2 and uncontrolled diabetes have had the highest risk for ED as a result of pituitary dysfunction that affects testosterone secretion.

\section{Correlation of BMI to Serum Testosterone}

In present study, BMI showed statistically significant results with total testosterone and free testosterone. Contrarily, a direct and significant relationship was observed between BMI and testosterone $(\mathrm{P}<0.05)$ in men with DM2.22

In present study, out of 80 patients $26(32.5 \%)$ were obese (BMI $>30 \mathrm{Kg} / \mathrm{mt}^{2}$ ) while in control group 10 out of $40(25 \%)$ were obese out of which $4(40 \%)$ had low serum free testosterone level. In our study, out of $26(32.5 \%)$ of obese patients with DM2, $16(61.51 \%)$ had low levels of total testosterone and 20 (76.9\%) had low serum free testosterone. Whereas Dhindsa et al23 (2010) reported prevalence of low testosterone in obese diabetics to be $50 \%$. The phenomenon of testosterone deficiency in diabetic patients with higher BMI could be due to increase in adipose tissues mass which results in increased aromatase activity, leading to enhanced conversion of testosterone in to estradiol 
which further suppresses hypothalamic-pituitary-testicular axis and decreases testosterone secretion (Giagulli et al24 1994). Adipose tissue, which is considered as an endocrine organ and produces a host of hormones and cytokines, may modulate insulin action and regulate Leydig cell function. Leptin production is tightly coupled to insulin resistance and may play a key role in steroid biogenesis and reduced testosterone levels. Leptin levels have been shown to be inversely correlated with serum testosterone levels (Haffner et al, 1997; Luukkaa et al, 1998), 25 and increased circulating leptin may be involved in the pathogenesis of Leydig cell dysfunction (Isidori et al26 1999). Other possible mechanism involved in pathogenesis of obesity related low testosterone is insulin resistance (Dhindsa et al ${ }^{23}$ 2010). In the present study out of 80 patients, $28(35 \%)$ were overweight and in out of these 28 patients, $16(57.14 \%)$ patients had decreased level of free testosterone.

Low BMI $\left(<18.5 \mathrm{Kg} / \mathrm{m}^{2}\right)$ was observed in 4 out of $80(5 \%)$ patients, of which 1 (25\%) had low free testosterone. Whereas, Dhindsa et al $^{24}$ (2010) observed that testosterone deficiency in lean diabetic patients was $44 \%$. This observation indicates that testosterone deficiency can occur even in diabetic patients with low BMI.

\section{CONCLUSION}

The present study finds testosterone deficiency in a significant proportion in type 2 DM patients irrespective of age and BMI. Low free testosterone level was found to be more significantly lower than low total testosterone in type 2 DM. Erectile dysfunction was found to be significant in type 2 DM developing in early phase of type $2 \mathrm{DM}$.

\section{REFERENCES}

[1] International Diabetes Federation. IDF Diabetes Atlas. Epidemiology and Morbidity. International Diabetes Federation 2011. http://www.idf.org/

[2] Powers AC. Diabetes Mellitus. Harrison's principles of internal medicine. Vol-2. 18 $8^{\text {th }}$ edn. McGraw-Hill 2012;344:2968-3003.

[3] Haffner SM, Miettinen H, Karhapäa P, et al. Leptin concentrations, sex hormones and cortisol in nondiabetic men. J Clin Endocrinol Metab 1997;82(6): 1807-9.

[4] Shores MM, Matsumoto AM, Sloan KL, et al. Low serum testosterone and mortality in male veterans. Arch Intern Med 2006;166(15):1660-5.

[5] Selvin E, Feinleib M, Zhang L, et al. Androgens and diabetes in men. Results from the Third National Health and Nutrition Examination Survey (NHANES III). Diabetes Care 2007;30(2):234-8.

[6] George JT, Veldhuis JD, Tena-Sempere $M$, et al. Exploring the pathophysiology of hypogonadism in men with type 2 diabetes: kisspeptin-10 stimulates serum testosterone and LH secretion in men with type 2 diabetes and mild biochemical hypogonadism. Clin Endocrinol (Oxf) 2013;79(1):100-4.

[7] Ghazi S, Zohdy W, Elkhiat Y, et al. Serum testosterone levels in diabetic men with and without erectile dysfunction. Andrologia 2012;44(6):373-80.

[8] Kohler TS, Kim J, Feia K, et al. Prevalence of androgen deficiency in men with erectile dysfunction. Urology 2008;71(4):693-7.
[9] Rezvani MR, Saadatjou SA, Sorouri S, et al. Comparison of serum free testosterone, luteinizing hormone and follicle stimulating hormone levels in diabetics and non-diabetics men - a case-control study. J Res Health Sci 2012;12(2):98-100.

[10] Tamler R, Deveney T. Hypogonadism, erectile dysfunction and type 2 diabetes mellitus: what the clinician needs to know. Postgrad Med 2010;122(6): 165-75.

[11] Romeo JH, Seftel AD, Madhun ZT, et al. Sexual function in men with diabetes type 2: association with glycemic control. J Urol 2000;163(3):788-91.

[12] Harman SM, Metter EJ, Tobin JD, et al. Longitudinal effects of aging on serum total and free testosterone levels in healthy men. Baltimore longitudinal study of aging. The Journal of Clinical Endocrinology Metabolism 2001;86(2):724-31.

[13] Shimokata H, Muller DC, Fleg JL, et al. Age as independent determinant of glucose tolerance. Diabetes 1991;40(1):44-51.

[14] Abate N, Haffner SM, Garg A, et al. Sex steroid hormones, upper body obesity and insulin resistance. The Journal of Clinical Endocrinology Metabolism 2002;87(10):4522-7.

[15] Goodman-Gruen D, Barrett-Connor E. Sex differences in the association of endogenous sex hormone levels and glucose tolerance status in older men and women. Diabetes Care 2000;23(7):912-8.

[16] Haffner SM, Shaten J, Stern MP, et al. Low levels of sex hormone binding globulin and testosterone predict the development of non-insulin dependent diabetes mellitus in men. MRFIT Research Group. Multiple Risk Factor Intervention Trial. Am Journal of Epidemiology 1996;143(9):889-97.

[17] El-Sakka AI, Hassoba HM, Sayed HM, et al. Pattern of endocrinal changes in patients with sexual dysfunction. Journal of Sexual Medicine 2005;2(4):551-8.

[18] American Diabetes Association (ADA). Clinical Practice Guidelines Expert Committee, American Diabetes Association, Clinical Practice Guidelines for the prevention and management of diabetes. Diabetes 2003;27(2):1-152.

[19] Health Central. Dyslipidemia causes erectile dysfunction, 2009 http://www.healthcentral.com/erectiledysfunction/c/936577/81208/dys/.

[20] Mohan V, Ravikumar R, Rani SS, et al. Intimal medial thickness of the carotid artery in South Indian diabetic and non-diabetic subjects: the Chennai Urban Population Study (CUPS). Diabetologia 2000;43(4):494-9.

[21] Mohan V, Gokulakrishnan K, Sandeep S, et al. Intimal media thickness, glucose intolerance and metabolic syndrome in Asian Indians - the Chennai Urban Rural Epidemiology Study (CURES -22). Diabetes Medicine 2006;23:845-50.

[22] Poretsky L. Principles of diabetes mellitus. 2nd edn. Springer Science 2010. 
[23] Dhindsa S, Miller MG, McWhirter CL, et al. Testosterone concentrations in diabetic and nondiabetic obese men. Diabetes Care 2010;33(6):1186-92.

[24] Giagulli VA, Kaufman JM, Vermeulen A. Pathogenesis of the decreased androgen levels in obese men. J Clin Endocrinal Metab 1994;79(4):997-1000.
[25] Luukkaa V, Pesonen U, Huhtaniemi I, et al. Inverse correlation between serum testosterone and leptin in men. J Clin Endocrinol Metab 1998;83(9):3243-6.

[26] Isidori AM, Caprio M, Strollo F, et al. Leptin and androgens in male obesity: evidence for leptin contribution to reduced androgen levels. J Clin Endocrinol Metab 1999;84(10):3673-80. 